\title{
The Prevention and Treatment of Malaria in Traditional Medicine of Tetun Ethnic People in West Timor Indonesia
}

\author{
Maximus M Taek ${ }^{1 *}$, Bambang Prajogo $\mathrm{EW}^{2}$ and Mangestuti Agil ${ }^{2}$ \\ 1Department of Chemistry, Faculty of Mathematics and Natural Sciences, Widya Mandira Catholic University, Kupang, Indonesia \\ 2Department of Pharmacognosy and Phytochemistry, Faculty of Pharmacy, Airlangga University, Surabaya, Indonesia \\ *Corresponding author: Maximus M Taek, Department of Chemistry, Faculty of Mathematics and Natural Sciences, Widya Mandira \\ Catholic University, Kupang, Indonesia
}

\begin{abstract}
Native people in West Timor Indonesia have been exposed to malaria since long time ago. Because of this experience, it is believed that this community has developed their local concept about malaria, and how to manage it. This research was intended to document and analyze local knowledge and practices of malaria prevention and treatment developed by Tetun ethnic people in West Timor. The research was a field study, conducted through some interviews, discussions and observations. The results of this study showed that this community has long been developing various methods to prevent and threat malaria. The prevention and treatment of malaria in traditional medicine of Tetun ethnic people consists of both herbal and non-herbal methods and supported by some prohibitions and restrictions. The results also showed that the practice of traditional medicine for prevention and treatment of malaria by Tetun ethnic people can be explained scientifically. Medicinal plants that widely used like Strychnos ligustrina, Carica papaya, Momordica sp., Cleome rutidosperma, Physalis angulata, Alstonia spectabilis, Alstonia scholaris and Melia azedarach have been proven to have antimalarial activities as anti-plasmodial, antipyretic, analgesic, anti-inflammatory and immunostimulant.
\end{abstract}

Keywords: Local Knowledge; Traditional Medicine; Malaria Prevention and Treatment; Tetun Ethnic; West Timor

\section{Introduction}

Traditional communities in ancient times developed their local knowledge about the prevention and treatment of a disease based on their experience interacting with the disease for a long time. This local knowledge was then become a guidance for them to establish strategies to prevent and treat the disease, which were practiced widely in the community, and become their traditional medicine $[1,2]$. Traditional medicine is a term imposed on pre-scientific medical systems, and defines as a sum total of knowledge, skills and practices based on theories, beliefs and experiences of different cultural customs used in health care, disease prevention and increased physical and mental performance, which have been used for generations from one generation to the next $[3,4]$. Malaria is an ancient disease that has not been fully eradicated until this time [5]. Since long time ago, malaria was the main infectious disease that often attacks Timorese people, especially in Belu and Malaka Districts in West Timor (Indonesia). Several old manuscripts noted that Timorese people in early of $19^{\text {th }}$ century were suffered from malaria which caused many deaths [6,7]. Until this time, Belu and Malaka Districts are still hyper-endemic areas of malaria. According to the Global Fund report, in 2014, Belu and Malaka Districts were classified as high malaria endemic areas, with the Annual Parasite Insidence (API) of $12.87 \mathrm{o} / \mathrm{oo}$ and $11.58 \mathrm{o} / \mathrm{oo}$ respectively, higher than Indonesian average API 1.380/oo. Various programs for malaria prevention and eradication sponsored by the Indonesian Ministry of Health and World Health Organization such as insecticide-impregnated net, fogging, mass blood survey for early diagnosis and prompt treatment, and treat malaria patient using Artemisinin Combination Therapy (ACT) have been implemented, but decreasing of the API value is still not too convincing [8]. Cultural factors that influence public attitudes and acceptance on the programs of prevention and treatment of malaria are estimated to be one of the obstacles to the success of these programs. The implementation of various disease control programs and strategies often faces major challenges stemming from the social and cultural 
situation of the community. The social and cultural situation of a community in a particular place can negatively influence the choice, acceptance and use of interventions in disease control. Many programs of disease control and eradication are unsuccessful because of these social and cultural barriers. Therefore, it is very necessary to understand the local knowledge of the community, including an understanding of the health-illness concept that they believe in. An understanding of this can help policy makers in designing a sustainable and more effective disease control programs [9]. The Tetun ethnic is one of native communities that inhabit territories from the central part of Timor island (in Belu and Malaka districts, Indonesia) to the east (in Republic Democratic de Timor Lester, RDTL). Tetun people are still using traditional medicines to date, and often running various traditional medication rituals [10]. Because of their long-time interaction with malaria, it should be assumed that they have developed their own local knowledge about malaria and methods to prevent and treat it. Therefore, this research was intended to study the local knowledge of the Tetun ethnic people regarding malaria and the methods they have developed for the prevention and treatment of this disease.

\section{Methods}

\section{Study Design}

This study is a kind of research in the field of medical anthropology. This study was conducted as a qualitative exploratory research, with a field study as main technique, supported by a literature study.

\section{Profile of Study Site and People}

This research was conducted in Belu and Malaka Districts located in the central part of Timor island. These areas are located at $9^{\circ} 15^{\prime} \mathrm{S}-9^{\circ} 34^{\prime} \mathrm{S}$ and $124^{\circ} 40^{\prime} \mathrm{E}-124^{\circ} 54^{\prime} \mathrm{E}$. Belu and Malaka are two of Indonesian territories that border directly with the Republic Democratic Timor Leste (RDTL). The topography of Belu Districts is mainly hilly, while Malaka is generally a stretch of flat land. Some areas of Malaka at the south part meet the rainy season twice in a year, while the areas of north part and also Belu areas are only have one rainy season. The main rainy season takes place between November-March due to wind that brings rain from the Indonesian Ocean. This rain occurs evenly in Malaka and Belu regions. The additional rainy season in April-June, which is limited in some areas of Malaka, is affected by wind from Australia that carries moisture from the Timor Sea. Based on the ethnolinguistics, there are four indigenous ethnic groups that live in Belu and Malaka Districts, namely Tetun, Dawan, Kemak, and Bunaq (Marae). Tetun ethnic is the majority ethnic group in Belu and Malaka, consists of approximately $80 \%$ of the population. They scaterred in almost all sub-districts of Belu and Malaka [11].

\section{The Informants}

The informants of this study were people of Tetun ethnic who have lived for long time in Belu or Malaka Districts. They were people with good knowledge and experiences of traditional medicine practices. The informants were selected through the purpossive and snowball tehniques. A total of 94 informants (42 men and 52 women) with the age of 40-90 years old were involved in this study. They came from 15 vilages of five sub-districts in Malaka (Wewiku, Malaka Barat, Weliman, Malaka Tengah and Kobalima Timur Subdistricts), and 14 vilages of ten sub-districts in Belu (Raimanuk, Tasifeto Barat, Nanaet Duabesi, Tasifeto Timur, Lasiolat, Raihat, Lamaknen, Kakuluk Mesak, Atambua Barat and Atambua Selatan Sub-districts). These informants consist of traditional public healers, home healers, and traditional medicine users.

\section{Data Collection}

Data were collected through several interviews, discussions, and observation. Interviews were conducted with a semi-structured questionnaire. Interviews were intended to collect informations about local knowledge on health-illness concept, symptoms, signs and causes of malaria, traditional methods for the prevention and treatment of malaria, and medicinal plants used for the prevention and treatment of malaria. More deep questions were developed spontaneously based on the answers given by the informants to the previous questions. Interviews and discussions were conducted in Tetun (local language) and Indonesian. We recorded the contents of every interview by wrote a detailed essence of the conversation, but not fully word by word. Several interviews were recorded with audio and video recorder. In this field study, we were assisted by several local guides to search for informants, accompanied in the interviews, to interpreted specific local terms that strange for us, and help us to search, document and collect plant specimens. All plants mentioned by informants were collected in-situ and documented by making photographs and herbaria for taxonomic identification. This field study was conducted from April 2017 to December 2017.

\section{Data Analysis}

Data obtained from interviews, discussions and observations were analyzed qualitatively, and presented in narrative or qualitative descriptions [12]. The steps of qualitative analysis are as follows:

a) Transcription of data: first of all, the interview data, discussions and field observation records were well-transcribed in a neat text.

b) Data reduction: transcripts were analyzed to marked meaningful parts, and then grouped based on the same characteristics into certain categories, i.e. the local knowledge about health-illness, local concepts about malaria, methods for the prevention and treatment of malaria, and plants used for the prevention and treatment of malaria.

c) Presentation of data: data that has been grouped were arranged regularly according to each category to make them easy to understand. Data of plants used in malaria prevention and treatment were presented in a table. 
d) Verification and conclusion: determined the meaning of the data presented.

\section{Results and Discussion}

\section{Local Concepts about Health-Illness}

The concept of health and illness in Tetun community is very simple. Tetun people define health as a condition of normal, good and not sick. Illness is interpreted as a condition in which someone feels unwell or sick or has a disease in the body. Tetun traditional people state a condition as health or ill by seeing physical signs. A person is said to be health if he/she looks physically strong, fresh, agile, has a bright face and good appetite; and vice versa, if the physical performance seems weak, lethargic, pale face, lack of appetite, then the person is said to be sick or has an illness in the body. Someone is said to have recovered from illness when showing physical signs such as being able to get up, not feel dizzy anymore, being able to walk quickly and to work again, and his/her appetite is back and improved. The concept of Tetun people about health and illness is also associated with the ability to carry out daily life activities. Someone who is still able to work or move without feeling bad or pain in his body, then that person is not said to be sick. People who are clinically suffering from a certain disease but not feel sick and still able to carry out daily activities without being disturbed by the disease, then that person is not considered sick. WHO and Indonesian Ministry of Health define health as a state of complete physical, mental and social well-being, and not merely the absence of diseases or infirmity [13]. Comparing the concept of health according to Tetun people's understanding with this official definition, it can be concluded that the concept of health of Tetun ethnic people is inadequate to describes whole condition called health, because for this community, health and illness are more related to physical performance than psychological and social performance.

\section{Local Concept about Symptoms and Signs, and Causes of Malaria}

The indigenous people of Tetun know malaria as is in mana's (hot body, fever) with primary signs and symptoms are high fever, shivering, intermittent fever, headache, muscle and joint pain, pale, yellow eyes, and abdominal pain and/or diarrhea. Many informants did not know that swollen spleen (splenomegaly) is also one of the signs of malaria that is already severe, but they assumed that the swollen spleen can cause fever (they say "malaria"). In general, almost all the informants assumed that malaria is a common, mild and not serious disease, only a sick of hot body or fever. This local concept seems to greatly influences people's perceptions of the danger of malaria and result in reduction of their alertness on malaria and the seriousness of managing this disease. In the local knowledge of Tetun ethnic people, the causes of malaria are: sweet food and drink, chilled, sunburn, fatigue, presence of other disease in the body, magic, cold food and drink, lack of sleep, inadequate post-natal care, spicy food, alcohol, and oily or fatty food. Tetun ethnic people assumed that sweet food and drink, sunburn, magic, spicy food, alcohol, and oily or fatty food cause an excessive heat in the body, and as a result, someone will get high fever malaria. Chilled, cold food and drink, lack of sleep is assumed to cause cold entering the body, and as the result, someone will get shivering malaria. The fatigue, presence of other disease in the body and inadequate post-natal care for mother and infant are assumed to destroy the equilibrium of hot and cold in the body and result in malaria with high fever and/or shivering. According to some informants, mosquito as malaria transmitter was a new knowledge that coming from outside, introduced by the Catholic missionaries from Europe. According to Foster dichotomous on causes of disease [14], the causes of malaria in the local concept of Tetun people are naturalistic, not personalistic. Factors such as sweet foods or drinks, long time in rain, water or cold places, long working under the hot sun, fatigue and the presence of other diseases in the body are naturalistic properties that cause heat-cold balance in the human body to be disrupted, and then causes someone to get malaria. Many Tetun people do not consider mosquito as carrier of malaria, causing them to have low awareness of the threat of mosquitoes. This may be one of the causes of the still high endemic of malaria in Belu and Malaka until this time [15].

\section{Methods for The Prevention and Treatment of Malaria}

The Tetun ethnic people have their own patterns or habits of life that they do for generations to prevent malaria attacks. The methods that are considered effective in preventing attacks of malaria are: luli or hale'u, drink medicinal concoction of bitter herbs, eat bitter food, and drink tua moruk. Luli or hale'u means avoiding things that can cause malaria (according to their local concepts about the cause of malaria), which are: not eating sweets frequently, not working for long time under the rain or hot sun, and not too tired at work or physical activities. Eating bitter foods, especially papaya and bitter melon, and drinking bitter palm sap tua moruk are also considered effective to prevent someone from being attacked by malaria. Some informants who previously linked malaria with mosquitoes stated that repelling mosquitoes using smoke of burned aromatic plants and sleeping under mosquito nets are effective for malaria prevention. The treatment of malaria in traditional medicine of Tetun ethnic consists of herbal and non-herbal methods. Herbal method consists of drinking herbal concoction, inhaling the vapor of boiled medicinal plant, massage with paste of medicinal plant, bath with water of boiled medicinal plant, and attach the paste of medicinal plant as a cataplasm on the swollen spleen. A non-herbal method is sunu kok, that is burning the waist above the swollen spleen using a piece of coconut shell coal or a heated metal. The results of the interviews showed that most traditional medication for malarial patient usually combine two or more methods. It was found also that the role of traditional healer in the treatment of malaria patient is not so important. Tetun ethnic people assumed that malaria is a common and not a serious disease, thus the treatment of malaria does not require a 
high competency healer. Several informants stated that they usually conducted self- and home-medication for malaria complaint. In the traditional medicine of Tetun ethnic people, the treatment of malaria is a simple treatment for reducing heat or fever [15]. The assumption of malaria as a common, mild and not a serious disease results in lack of awareness about dangers of malaria. It was found that in many cases, health workers often complain of disobedience of patients who stop taking antimalarial drugs immediately after they feel cured (being able to get up, not feel dizzy anymore, being able to work again, and the appetite is improved), even though Plasmodium in their blood has not been completely eliminated. As the result, the success of the malaria eradication program in this area has increased very slowly [8].

\section{Plants Used for The Prevention of Malaria}

Tetun ethnic people believe that consumption of bitter food or drink can prevent someone from malaria attacks. Therefore, small children are often forced by their parents to eat stew and drink decoctions of flowers, leaves and young fruit of Carica papaya, or young fruit of Momordica sp. (M. charantia or M. balsamina). Some informants gave information that if they feel tired, achy and lack of appetite, they will drink decoction of Carica papaya leaves, fruit of Momordica charantia, Melia azadarach leaves, Alstonia scholaris, Alstonia spectabilis or Strychnos ligustrina stem bark. Consumption of these plants' decoction is believed to restoring body freshness, increasing appetite, eliminating fatigue, and thus, preventing from malaria attack. Some informants also believed that drinking tua moruk is effective in malaria preventon. Tua moruk is a traditional drink made by fresh tapped palm sap soaked with the stem bark of

Alstonia scholaris, Alstonia spectabilis or Strychnos ligustrina soaked in it. Several publications of other previous studies showed that the bitter plants used by Tetun people to prevent malaria has been shown to have pharmacological activities as antiplasmodium and immunostimulant [16-18].

\section{Plants Used for The Treatment of Malaria}

In this study, we recorded a total of 96 species from 39 families used by Tetun people in various formula for drink, massage, bath, inhalation and cataplasm (Table 1). Strychnos ligustrina, Carica papaya, Cleome rutidosperma, Physalis angulata, Alstonia spectabilis, Alstonia scholaris and Melia azedarach are some of the most widely plants used in various formula for drink. For massage, Garuga floribunda, Jatropha curcas, Acorus calamus, Allium cepa, Drynaria quercifolia, Ocimum sp. and Ruta graveolens are common. For bathing, people use Tamarindus indica, Psidium guajava, Melicope latifolia and Blumea balsamifera. Leaves of Brucea javanica, Annona muricata and Annona reticulata are used in inhalation method. Root of Moringa oleifera and leaves of Ficus hispida are used as cataplasm to reduce the swollen spleen [19]. Several plants were found in various formula for more than one mode of application. Several previous publications showed that most of these plants are also used in other traditional medicine for the same purpose in many areas of Indonesia and the world $[16,18]$, and have been scientifically proven to have pharmacological activities as true antimalarial (antiplasmodial) and/or indirect antimalarial such as antipyretic, analgesic, anti-inflammatory and immunostimulant [20].

Table 1: Plants used by Tetum ethnic people for the treatment of malaria.

\begin{tabular}{|c|c|c|c|c|c|}
\hline Scientific Name and Family & Local Name & Source & Part(s) Used & $\begin{array}{c}\text { Mode of } \\
\text { Preparation }\end{array}$ & $\begin{array}{c}\text { Mode of } \\
\text { Administration }\end{array}$ \\
\hline Acacia farnesiana (L.) Willd. (Fabaceae) & Bakuro & Wild & Leaf & Boil & Bath \\
\hline Acacia leucophloea (Roxb.) Willd. (Fabaceae) & Besak & Wild & Bark & Infusion & Drink \\
\hline \multirow{2}{*}{ Acorus calamus L. (Acoraceae) } & \multirow{2}{*}{ Knuan } & \multirow{2}{*}{ Cultivated } & \multirow{2}{*}{ Rhizome } & Paste & Massage \\
\hline & & & & Boil & Bath \\
\hline \multirow{3}{*}{ Aegle marmelos (L.) Correa (Rutaceae) } & \multirow{3}{*}{ Dilafatuk } & \multirow{3}{*}{ Wild } & \multirow{2}{*}{ Bark, root } & Decoction & Drink \\
\hline & & & & Paste & Massage \\
\hline & & & Leaf & Boil & Bath \\
\hline Aeschynomene americana L. (Fabaceae) & Ai moe lalek & Wild & Root, leaf & Paste & Massage \\
\hline $\begin{array}{l}\text { Aleuritas moluccana (L.) Willd. } \\
\text { (Euphorbiaceae) }\end{array}$ & Badut mi & Cultivated & Kernel & Paste & Massage \\
\hline Allium cepa L. (Amaryllidaceae) & Lisa mean & Cultivated & Clove & Paste in coconut oil & Massage \\
\hline Allium sativum L. (Amaryllidaceae) & Lisa mutin & Cultivated & Clove & Paste in coconut oil & Massage \\
\hline \multirow{2}{*}{ Alstonia scholaris (L.) R.Br. (Apocynaceae) } & \multirow{2}{*}{ Kroti mutin } & \multirow{2}{*}{ Wild } & \multirow{2}{*}{ Bark } & Decoction & Drink \\
\hline & & & & Boil & Bath \\
\hline \multirow{2}{*}{ Alstonia spectabilis R.Br. (Apocynaceae) } & \multirow{2}{*}{ Kroti metan } & \multirow{2}{*}{ Wild } & Bark, leaf & Decoction & Drink \\
\hline & & & Bark & Boil & Bath \\
\hline \multirow{2}{*}{$\begin{array}{c}\text { Andrographis paniculata (Burm.f.) Wall. } \\
\text { (Acanthaceae) }\end{array}$} & \multirow{2}{*}{ Karlulu } & \multirow{2}{*}{ Wild } & \multirow{2}{*}{ Whole plant } & Decoction & Drink \\
\hline & & & & Boil & Bath \\
\hline Annona muricata L. (Annonaceae) & Ata bot & Cultivated & Leaf & Boil & Inhalation \\
\hline
\end{tabular}




\begin{tabular}{|c|c|c|c|c|c|}
\hline Annona squamosa L. (Annonaceae) & Ata lotu & Cultivated & Leaf & Boil & Bath \\
\hline \multirow{2}{*}{ Annona reticulata L. (Annonaceae) } & \multirow{2}{*}{ Ata malae } & \multirow{2}{*}{ Wild } & \multirow{2}{*}{ Leaf } & \multirow{2}{*}{ Boil } & Bath \\
\hline & & & & & Inhalation \\
\hline Artocarpus incisa (Thunb.) L.f. (Moraceae) & Kulu & Wild & Leaf & Boil & Bath \\
\hline Atalantia trimera (Oliv.) Burkill. (Rutaceae) & Asulerok & Wild & Leaf & Paste & Massage \\
\hline Averrhoa bilimbi L. (Oxalidaceae) & Blidin lotu & Cultivated & Leaf & Boil & Bath \\
\hline Averrhoa carambola L. (Oxalidaceae) & Blidin wai & Wild & Leaf & Boil & Bath \\
\hline \multirow{3}{*}{ Blumea balsamifera (L.) DC. (Compositae) } & \multirow{3}{*}{ Fafok } & \multirow{3}{*}{ Wild } & \multirow{3}{*}{ Bark } & Decoction & Drink \\
\hline & & & & Paste & Massage \\
\hline & & & & Boil & Bath \\
\hline Bridelia ovata Decne. (Euphorbiaceae) & Knabu & Wild & Leaf & Decoction & Drink \\
\hline \multirow{3}{*}{ Brucea javanica (L.) Merr. (Simaroubaceae) } & \multirow{3}{*}{ Ai lakar } & \multirow{3}{*}{ Wild } & \multirow{3}{*}{ Leaf, bark, root } & Decoction & Drink \\
\hline & & & & \multirow{2}{*}{ Boil } & Bath \\
\hline & & & & & Inhalation \\
\hline \multirow{4}{*}{$\begin{array}{l}\text { Calotropis gigantea (L.) R. Br. } \\
\text { (Asclepediaceae) }\end{array}$} & \multirow{4}{*}{ Fuka } & \multirow{4}{*}{ Wild } & \multirow{2}{*}{ Root } & Decoction & Drink \\
\hline & & & & Paste & Massage \\
\hline & & & \multirow{2}{*}{ Leaf } & Boil & Bath \\
\hline & & & & Whole leaf or paste & Cataplasm \\
\hline Capsicum annuum L. (Solanaceae) & $\begin{array}{l}\text { Masimanas, } \\
\text { kunus }\end{array}$ & Cultivated & Fruit & Decoction & Drink \\
\hline \multirow{3}{*}{ Carica papaya L. (Caricaceae) } & \multirow{3}{*}{ Dila } & \multirow{3}{*}{ Cultivated } & \multirow{2}{*}{ Leaf } & Decoction & Drink \\
\hline & & & & Boil & Bath \\
\hline & & & Root & Paste & Cataplasm \\
\hline & & & & Decoction & Drink \\
\hline 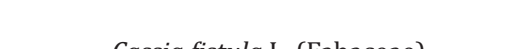 & I. & MI:lld & Bark & Paste & Massage \\
\hline Cassia fistula L. (Fabaceae) & Liman tohar & Wild & & Boil & Bath \\
\hline & & & Leaf & Whole leaf or paste & Cataplasm \\
\hline & & & Bark & Decoction & Drink \\
\hline Cassia siamea Lam. (Fabaceae) & Krui & Wild & Jenf & Boil & Bath \\
\hline & & & Leal & Boil & Bath \\
\hline Ceiba pentandra (L) Gaertn (Malvaceae) & Kabidawa & Cultivated & Leaf & Decoction & Drink \\
\hline Ceıba pentandra (L.) Gaertn. (Malvaceae) & Kabidawa & Cultivated & Leat & Paste & Massage \\
\hline Citrus aurantifolia (Christm.) Swingle. & & & & Paste & Massage \\
\hline (Rutaceae) & Derok masin & Cultivated & Leaf & Boil & Bath \\
\hline Cleome aunandra I (Connorocene) & I loum & Wild & Whole plant & Decoction & Drink \\
\hline creome gynanara L. (Lapparaceae) & Lakaur & Vild & Leaf & Paste & Massage \\
\hline$C$. & Wolos & Willd & I & Decoction & Drink \\
\hline Coccınıa grandis (L.) Voigt. (Cucurbitaceae) & Kabasa & Wild & Leat & Boil & Bath \\
\hline $\begin{array}{l}\text { Cordyline fructicosa (L.) A. Chev. } \\
\text { (Asparagaceae) }\end{array}$ & Riman isin & Wild & Leaf & Paste & Massage \\
\hline C. . & T has & Nulul & Leaf & Maceration & Bath \\
\hline Crınum asıatıcum L. (Amarylıdaceae) & Taborut & Wild & Tuber & Paste & Massage \\
\hline & & & & Decoction & Drink \\
\hline Curcuma domestica Val. (Zingiberaceae) & Kinur & Cultivated & Rhizome & Paste & Massage \\
\hline Dendropthoe pentandra (L) Miq. & Tautiuten & wild & Jeof borl & Decoction & Drink \\
\hline (Loranthaceae) & rau tru ten & VVIId & Leai, Dark & Paste & Massage \\
\hline $\begin{array}{l}\text { Drynaria quercifolia (L.) J. Smith. } \\
\text { (Polypodiaceae) }\end{array}$ & Manliras & Wild & Tuber & Paste & Massage \\
\hline Dysoxylum gaudichaudianum (A. Juss.) Miq. & Modalacon & Wild & Lopf & Decoction & Drink \\
\hline (Meliaceae) & Iveua rasan & VVIIU & Ledi & Boil & Bath \\
\hline
\end{tabular}




\begin{tabular}{|c|c|c|c|c|c|}
\hline Elephantopus scaber L. (Compositae) & Krau kidan & Wild & Leaf & Paste & Massage \\
\hline Eucaliptus alba Reinw. (Myrtaceae) & Bubur & Wild & Leaf & Boil & Bath \\
\hline Eugenia sp. (Myrtaceae) & Ai siba & Wild & Leaf & Boil & Bath \\
\hline Euphorbia nerifolia L. (Euphorbiaceae) & Klatun dian & Wild & Stem & Boil & Bath \\
\hline Fatoua pilosa Gaudich. (Moraceae) & Lorowen & Wild & Root & Decoction & Drink \\
\hline Ficus callosa Willd. (Moraceae) & Salur & Wild & Bark & Decoction & Drink \\
\hline \multirow{2}{*}{ Ficus hispida L.f. (Moraceae) } & \multirow{2}{*}{ Baulenuk } & \multirow{2}{*}{ Wild } & \multirow{2}{*}{ Leaf } & Decoction & Drink \\
\hline & & & & Paste & Cataplasm \\
\hline \multirow{2}{*}{ Ficus septica Burm.f. (Moraceae) } & \multirow{2}{*}{ Mamumus } & \multirow{2}{*}{ Wild } & \multirow{2}{*}{ Leaf } & \multirow{2}{*}{ Paste } & Massage \\
\hline & & & & & Cataplasm \\
\hline Ficus virens L. (Moraceae) & Hali & Wild & Leaf & Boil & Bath \\
\hline $\begin{array}{c}\text { Flengimia macrophylla (Wild.) Merr. } \\
\text { (Fabaceae) }\end{array}$ & Sakiki mean & Wild & Leaf & Boil & Bath \\
\hline \multirow{2}{*}{ Garuga floribunda Decne. (Burseraceae) } & \multirow{2}{*}{ Feu } & \multirow{2}{*}{ Wild } & \multirow{2}{*}{ Bark } & Decoction & Drink \\
\hline & & & & Paste & Massage \\
\hline \multirow{3}{*}{ Gossypium hirsutum L. (Malvaceae) } & \multirow{3}{*}{$\begin{array}{l}\text { Kabas fuan } \\
\text { mean }\end{array}$} & & \multirow{3}{*}{ Root } & Decoction & Drink \\
\hline & & & & Paste & Massage \\
\hline & & & & Boil & Bath \\
\hline Grewia koodersiana Burrett. (Tilliaceae) & Lenok & Wild & Root & Decoction & Drink \\
\hline $\begin{array}{l}\text { Gymnopetalum leucosticum Miq. } \\
\text { (Cucurbitaceae) }\end{array}$ & Kolokoen & Wild & Root & Decoction & Drink \\
\hline \multirow{2}{*}{ Hyptis suaveolans (L.) Poit. (Asteraceae) } & \multirow{2}{*}{ Ai dois metan } & \multirow{2}{*}{ Wild } & \multirow{2}{*}{ Leaf } & Paste & Massage \\
\hline & & & & Boil & Bath \\
\hline Imperata cylindrica (L.) P. Beauv. (Poaceae) & Hae manlain & Wild & Root & Decoction & Drink \\
\hline \multirow{3}{*}{ Indigofera suffruticosa Mill. (Fabaceae) } & \multirow{3}{*}{ Taun } & \multirow{3}{*}{ Wild } & & Decoction & Drink \\
\hline & & & Leaf & Boil & Bath \\
\hline & & & & Paste & Massage \\
\hline & & & & Decoction & Drink \\
\hline Jatronhacurcas L (Funhorbiaceae) & Badut malaka & wild & Bark & Paste & Massage \\
\hline Jacropna curcas L. (Eupnordaceae) & mutin & WVIId & Bark & Boil & Bath \\
\hline & & & & Boil & Inhalation \\
\hline Iatronhagoscunifolia I (Funhorhizceวe) & Badut malaka & wild & Bark & Decoction & Drink \\
\hline jatropna gossypijoila L. (Eupnordiaceae) & mean & Vild & Bark & Paste & Massage \\
\hline Lantana camara L. (Verbenaceae) & Tateka & Wild & Leaf & Boil & Bath \\
\hline $\begin{array}{l}\text { Macaranga tanarius (L.) Mull. Arg. } \\
\text { (Euphorbiaceae) }\end{array}$ & Tubi tahak & Wild & Leaf & Boil & Bath \\
\hline & & & Bark, leaf & Decoction & Drink \\
\hline Melia azedarach L. (Meliaceae) & Samer & Wild & Leaf & Paste & Massage \\
\hline & & & Ledi & Boil & Bath \\
\hline Melicope latifolia (DC.) T.G. Hartley & Aitahantolut & wild & Leaf & Paste & Massage \\
\hline (Rutaceae) & Al tahan tolu & Wila & Leai & Boil & Bath \\
\hline Melodorum fruticosum Lour. (Annonaceae) & Ai leu lahat & Wild & Leaf & Paste & Massage \\
\hline & & & Leaf, fruit & Juice, decoction & Drink \\
\hline Momordica balsamina L. (Cucurbitaceae) & Bria fuik & Wild & Leaf & Paste & Massage \\
\hline & & & Leal & Boil & Bath \\
\hline Morinda citrifolia L. (Rubiaceae) & Nenuk & Wild & Leaf, fruit, bark & Decoction & Drink \\
\hline Moringa oleifera I am (Moringaceae) & Mánt & Sultivated & Ront & Pacte & Massage \\
\hline Moringa oletjera Lam. (IVormgaceae) & Ma ut & curtivated & KOOt & Paste & Cataplasm \\
\hline & Kafiru & Wild & Bark & Decoction & Drink \\
\hline Nauclea orientalis (L.) L. (Rubiaceae) & Karıru & VWila & Bark & Paste & Massage \\
\hline
\end{tabular}




\begin{tabular}{|c|c|c|c|c|c|}
\hline $\begin{array}{l}\text { Neoalsomitra podagrica Steenis } \\
\text { (Cucurbitaceae) }\end{array}$ & Masin borat & Wild & Root, stem & Decoction, infusion & Drink \\
\hline \multirow{2}{*}{ Ocimum americanum L. (Lamiaceae) } & \multirow{2}{*}{ Silasi mean } & \multirow{2}{*}{ Wild } & \multirow{2}{*}{ Leaf } & Paste in coconut oil & Massage \\
\hline & & & & Boil & Bath \\
\hline Ocimum basillicum L. (Lamiaceae) & Silasi mutin & Cultivated & Leaf & Paste in coconut oil & Massage \\
\hline $\begin{array}{c}\text { Operculina turpethum (L.) Silva Manso. } \\
\text { (Convolvulaceae) }\end{array}$ & Kaboen fuik & Wild & Leaf & Boil & Bath \\
\hline Phyllanthus niruri L. (Phyllanthaceae) & Renes & Wild & Whole plant & Decoction & Drink \\
\hline Phyllanthus reticulatus Poir. (Phyllanthaceae) & Klan & Wild & Leaf & Paste & Massage \\
\hline Physalis angulata L. (Solanaceae) & Babotore & Wild & Whole plant & Decoction & Drink \\
\hline \multirow{3}{*}{ Piper betle L. (Piperaceae) } & \multirow{3}{*}{ Fuik } & \multirow{3}{*}{ Cultivated } & \multirow{3}{*}{ Leaf } & \multirow{2}{*}{ Paste } & Massage \\
\hline & & & & & Cataplasm \\
\hline & & & & Boil & Bath \\
\hline \multirow{2}{*}{ Piper cubeba L.f. (Piperaceae) } & \multirow{2}{*}{ Kunus aleten } & \multirow{2}{*}{ Wild } & \multirow{2}{*}{ Leaf } & Decoction & Drink \\
\hline & & & & Paste & Massage \\
\hline $\begin{array}{l}\text { Pittosporum timorense Blume. } \\
\text { (Pittosporaceae) }\end{array}$ & Ai feto & Wild & Bark & Paste & Massage \\
\hline Plumeria alba L. (Apocynaceae) & Mukrin & Wild & Bark & Decoction & Drink \\
\hline Psidium guajava L. (Myrtaceae) & Koya & Wild & Leaf & Boil & Bath \\
\hline Ruta angustifolia Pers. (Rutaceae) & Aruda & Cultivated & Leaf & Paste in coconut oil & Massage \\
\hline \multirow{2}{*}{ Schleichera oleosa (Lour.) Oken (Sapindaceae) } & \multirow{2}{*}{ Sukabi } & \multirow{2}{*}{ Wild } & \multirow{2}{*}{ Leaf } & Paste & Massage \\
\hline & & & & Boil & Bath \\
\hline Senna tora (L.) Roxb. (Fabaceae) & Frasuk ten & Wild & Leaf & Boil & Bath \\
\hline \multirow{2}{*}{ Sesbania grandiflora (L.) Poiret. (Fabaceae) } & \multirow{2}{*}{ Kala mean } & \multirow{2}{*}{ Wild } & \multirow{2}{*}{ Leaf } & Paste & Massage \\
\hline & & & & Boil & Bath \\
\hline \multirow{2}{*}{ Solanum lycopersicum L. (Solanaceae) } & \multirow{2}{*}{ Kaut } & \multirow{2}{*}{ Wild } & Jopf & Paste & Massage \\
\hline & & & LeaI & Boil & Bath \\
\hline Storculia footida I (Ctorculiaceno) & Ahano $\mathrm{O}$ & Wlild & Parle $\mathrm{C}+\mathrm{C}$ & Decoction & Drink \\
\hline sercuila joецаa L. (stercunaceae) & ADano & VIII & Bark & Paste & Massage \\
\hline Struchnoc liaustring Plume(I & Rolvumoru & Wild & Stem, bark & Decoction, infusion & Drink \\
\hline strycnnos ilgustrina siume (Loganracede) & Бакumoru & VVIIU & Leaf & Boil & Bath \\
\hline Swietenia macrophylla King (Meliaceae) & Mahoni & Wild & Seed & Raw seed & Drink \\
\hline $\begin{array}{c}\text { Syzygium aqueum (Burm.f.) Alston } \\
\text { (Myrtaceae) }\end{array}$ & Beko & Wild & Leaf & Boil & Bath \\
\hline Syzygium cumini (L.) Skeels. (Myrtaceae) & Ai malae & Wild & Leaf & Paste & Massage \\
\hline Tabernaemontana pandacaqui Lam. & Jalitin mane & wild & Bark, root & Decoction & Drink \\
\hline (Apocynaceae) & Lantint indane & Vvilu & Leaf & Paste & Massage \\
\hline & & & & Decoction & Drink \\
\hline Tamarindus indica L. (Fabaceae) & Sukaer & Wild & Leaf & Paste & Massage \\
\hline & & & & Boil & Bath \\
\hline Uvaria rufa Blume (Annonaceae) & Koke lotu & Wild & Root & Decoction & Drink \\
\hline Vitex trifolia L. (Lamiaceae) & Ai tatasik & Wild & Leaf & Paste & Massage \\
\hline 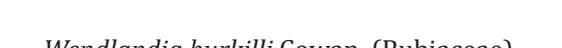 & Votiman & wild & Dank $\mathrm{k}+\mathrm{C}$ & Decoction & Drink \\
\hline Wendlandıa burkıllı cowan. (Rubıaceae) & Katımun & Wild & Bark & Paste & Massage \\
\hline & & & Bark, root & Decoction & Drink \\
\hline Wrightia pubescens R.Br. (Apocynaceae) & Lalitin feto & Wild & Ioof & Paste & Massage \\
\hline & & & Ledi & Boil & Bath \\
\hline Zingiber officinale Roscoe. (Zingiberaceae) & Masimanas kee & Cultivated & Rhizome & Paste & Massage \\
\hline
\end{tabular}




\begin{tabular}{|c|c|c|c|c|c|}
\hline \multirow{2}{*}{ Ziziphus timoriensis DC. (Rhamnaceae) } & \multirow{2}{*}{ Ai sisi } & \multirow{2}{*}{ Wild } & Leaf, bark & Decoction & Drink \\
\hline & & & Bark & Paste & Massage \\
\hline Not identified & Moat tiris & Wild & Leaf & Decoction & Drink \\
\hline Not identified & Uas laomea & Wild & Tuber & Decoction & Drink \\
\hline
\end{tabular}

\section{Conclusion}

The practice of preventing and treating malaria in the traditional medicine of Tetun ethnic people is a direct implementation of their local knowledge about malaria. The local concept of signs and symptoms and the causes of malaria encourage traditional people to create methods to prevent and treat malaria. The local concept of the Tetun ethnic people about malaria is the main reference in the creation of rules regarding prohibitions and restrictions, and recommendations for preventing attacks of malaria. The local concept of the causes of malaria determines the choice of plants for the treatment of malaria. Scientifically, these plants have been proven to have activities as true antimalarial and indirect antimalarial. The local concept of malaria as a common, mild and harmless disease causes that the role of traditional healer is not always needed in the treatment of malaria. Methods for the prevention and treatment of malaria developed by Tetun ethnic people consist of both herbal and non-herbal methods and supported by the implementation of several prohibitions and restrictions to provide healing for the sufferers of malaria.

\section{Acknowledgement}

We thank to Indonesian Ministry of Research, Technology and Higher Education, for financial support (Research Contract No. 0668/K8/KM/2018).

\section{References}

1. Bivins R (2009) Alternative medicine? A history. Oxford: Oxford University Press, USA.

2. Heinrich M (2003) Ethnobotany and natural product: the search for new molecules, new treatment of old diseases or a better understanding of indigenous cultures? Current Topics in Med Chem 3(2): 29-42.

3. Choi SH (2008) WHO traditional medicine strategy and activities Standardization with evidence-based approaches. J Acupuncture Meridian Study 1(2): 153-154.

4. Saroya AS (2010) Herbalism Phytochemistry and ethnopharmacology. Enfield New Hampshire: Science Publishers.
5. Schwikkard S van Heerden F (2002) Antimalarial activity of plant metabolites. Nat Prod Rep 19(5): 675-692.

6. Embuiru H (1998) Sejarah Gereja Katolik di Timor jilid 2. Ende: Penerbit Nusa Indah.

7. Wellem FD (2006) Kamus Sejarah Gereja Jakarta: Penerbit BPK Gunung Mulia.

8. Global Fund for Malaria (2015) Laporan tentang Malaria di NTT tahun 2014. Kupang: Dinas Kesehatan Provinsi NTT.

9. Serengbe GB, Moyen JM, Fioboy R, Beyam EN, Kango C et al. (2015) Knowledge and perceptions about malaria in communities in four districts of the Central African Republic. BMC Res Notes 8: 162.

10. Taek MM, Mali S (2017) Plants in ai tahan: traditional medicine of the Tetun ethnic community in West Timor Indonesia. In: Proc 7th Annual Basic Science Int Conf. Malang: Brawijaya University pp71-76.

11. Seran HJ (2007) Ema Tetun Kupang: Penerbit Gita Kasih.

12. Idrus M (2009) Metode Penelitian Ilmu Sosial, Pendekatan Kualitatif dan Kuantitatif, edisi kedua Jakarta: Penerbit Erlangga.

13. Undang Undang Kesehatan Republik Indonesia No. 36 Tahun 2009.

14. Foster GM, Anderson BG (1986) Antropologi Kesehatan Diterjemahkan oleh: Suryadarma PP dan Swasono MFH.

15. Taek MM, Prajogo BEW, Agil M (2018) Ethnomedicinal plants used for the treatment of malaria in Malaka, West Timor. J Young Pharm 10(2): 187-192.

16. Trimurningsih T, Subeki S, Matsuura H, Takahashi K, Yamasaki M,et al. (2005). Evaluation of the inhibitory activities of the extracts of Indonesian traditional medicinal plants against Plasmodium falciparum and Babesia gibsoni. J Vet Med Sci; 67(8): 829-881.

17. Abdillah S, Tambunan RM, Farida Y, Sandhiutami NMD, Dewi RM (2015) Phytochemical screening and antimalarial activity of some plants traditionally used in Indonesia. Asian Pac J Trop Dis 5(6): 454-457.

18. Charturvedi P, Raseroka BH, Ntshebe $O$ (2006) Evaluation of antimalarial activity of Melia azedarach. J Appl Zool Res 17(1): 109-113.

19. Abdillah S, Tambunan RM, Sinaga YM, Farida Y (2014) Ethnobotanical survey of plants used in the traditional treatment of malaria in Sei Kepayang, Asahan of North Sumatera. Asian Pac J Trop Med Supplement 7S1: 104-107.

20. Mambu L, Grellier P (2007) Antimalarial compounds from traditionally used medicinal plants. In: Colegate SM, Molyneux RJ (eds). Bioactive natural products: Detection, isolation and structural determination. $2^{\text {nd }}$ edn. 


\section{(c) (i)}

This work is licensed under Creative Commons Attribution 4.0 License

To Submit Your Article Click Here:

Submit Article

DOI: 10.32474/OAJCAM.2019.01.000121

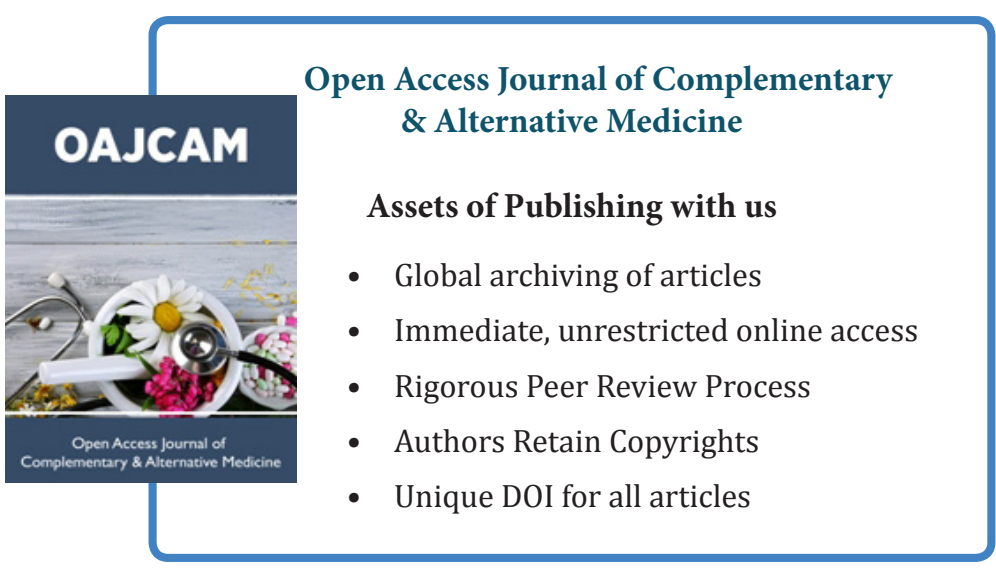

